\title{
PENGARUH CURRENT RATIO, DEBT TO EQUITY RATIO, TOTAL ASSET TURNOVER DAN KEPEMILIKAN MANAJERIAL TERHADAP PERTUMBUHAN LABA
}

\author{
${ }^{1}$ Nadia Hanifah \\ ${ }^{2}$ Kartika Hendra Ts \\ ${ }^{3}$ Siti Nurlaela \\ ${ }^{1,2,3}$ Program Studi Akuntansi, Universitas Islam Batik Surakarta \\ email: nadiahanyfa@gmail.com
}

\begin{abstract}
Earnings growth is an increase in profit or decline in profit per year and can be used to assess how the development of a company's performance. The purpose of this study is to examine and analyze the effect of current ratio, debt to equity ratio, total asset turnover and managerial ownership on earnings growth. The population in this study is the banking sub-sector companies listed on the Indonesia Stock Exchange for the period of 2016-2018. The sampling technique in this study used a purposive sampling method and obtained a sample of 20 companies. The data analysis method uses the classic assumption test and multiple linear regression analysis using SPSS 20, with the results of data analysis showing that, debt to equity ratio and managerial ownership influence earnings growth. While the current ratio and total asset turnover has no effect on profit growth.

Keywords : Profit Growth, Current Ratio, Debt to Equity Ratio, Total Aset Turnover, Managerial Ownership
\end{abstract}

\begin{abstract}
Abstrak
Pertumbuhan Laba merupakan kenaikan laba atau penurunan laba per tahun yang dapat digunakan untuk menilai bagaimana perkembangan kinerja suatu perusahaan. Tujuan dari penelitian ini adalah untuk menguji dan menganalisis pengaruh current ratio, debt to equity ratio, total asset turnover dan kepemilikan manajerial terhadap pertumbuhan laba. Populasi dalam penelitian ini adalah perusahaan sub sektor perbankan yang terdaftar di Bursa Efek Indonesia periode 2016-2018. Teknik pengambilan sampel dalam penelitian ini menggunakan metode purposive sampling dan diperoleh sampel sebanyak 20 perusahaan. Metode analisis data menggunakan uji asumsi klasik dan analisis regresi linier berganda menggunakan SPSS 20, dengan hasil analisis data menunjukkan bahwa, debt to equity ratio dan kepemilikan manajerial berpengaruh terhadap pertumbuhan laba. Sedangkan current ratio dan total asset turnover tidak berpengaruh terhadap pertumbuhan laba.

Kata Kunci : Pertumbuhan Laba, Current Ratio, Debt to Equity Ratio, Total Aset Turnover, Kepemilikan Manajerial
\end{abstract}

\section{PENDAHULUAN}

Tujuan dari setiap aktivitas usaha adalah memaksimalkan laba. Laba merupakan salah satu ukuran kinerja perusahaan. Kasmir (2017, hal 302) "Laba atau keuntungan merupakan salah satu tujuan utama perusahaan dalam menjalankan aktivitasnya. Pihak manajemen selalu merencanakan besar perolehan laba setiap periodnya yang ditentukan melalui target yang harus dicapai". Disamping memperoleh keuntungan, manajemen dituntut untuk oleh pemegang saham untuk meningkatkan pertumbuhan laba. Pertumbuhan Laba merupakan kenaikan laba atau penurunan laba per tahun. Pertumbuhan laba dapat digunakan untuk menilai bagaimana perkembangan kinerja suatu perusahaan. Maka semakin tinggi laba yang dicapai suatu perusahaan, mengindikasikan semakin baik kinerja perusahaan.

Hanafi (2009) Current Ratio adalah rasio yang digunakan untuk mengukur kemampuan perusahaan dalam membayar kewajiban jangka pendek atau hutang yang segera jatuh tempo pada saat ditagih secara keseluruhan. Current ratio dapat menjelaskan kemampuan 
perusahaan memenuhi hutang jangka pendeknya menggunakan aktiva lancarnya (aktiva yang akan merubah kas dalam waktu satu tahun atau satu siklus bisnis).

Kasmir (2012, hal 166) Debt to Equity Ratio merupakan rasio yang digunakan untuk mengetahui perbandingan antara total utang dengan modal sendiri. Prihantoro (2009) Debt to Equity Ratio berguna untuk mengetahui seberapa besar aktiva perusahaan dibiayai dari utang. Oleh karena itu, semakin rendah Debt to Equity Ratio akan semakin tinggi kemampuan perusahaan untuk membayar semua kewajibannya. Semakin besar penggunaan hutang maka dapat berdampak pada financial distress dan kebangkrutan.

Sawir (2003, hal 19) Total Asset Turnover atau perputaran total aktiva adalah kecepatan berputarnya total asset dalam suatu periode tertentu. Rasio ini biasanya digunakan untuk mengukur seberapa efektifnya pemanfaatan aktiva dalam menghasilkan penjualan. Total Asset Turnover yang rendah dapat diartikan bahwa penjualan bersih perusahaan lebih kecil dari pada operating asset perusahaan. Jika perputaran aktiva perusahaan tinggi maka akan semakin efektif perusahaan dalam mengelola aktivitasnya oleh Irawati (2006).

Imanta (2011, hal 68) Kepemilikan Manajerial adalah kepemilikan saham perusahaan oleh pihak manajer atau sebagai pemegang saham. Manajer yang memiliki saham dalam perusahaan akan berusaha meningkatkan kinerja perusahaan, karena apabila manajer dapat meningkatkan laba perusahaan makin intensif yang akan didapatkan manajer tersebut akan meningkat. Kepemilikan manajer ini akan membuat manajemen semakin bertanggung jawab atas perusahaanya dan mengurangi resiko keuangan yang tidak baik yang dapat mempengaruhi operasional perusahaan oleh Tarigan (2007).

Yanti (2017) dengan sampel 12 Perusahaan sub sektor Makanan dan Minuman yang Terdaftar di BEl Tahun 2010-2016. Menunjukkan hasil bahwa Debt to Equity Ratio, Current Ratio, dan Net Profit Margin tidak berpengaruh terhadap Pertumbuhan Laba. Sementara Return on Asset memiliki pengaruh terhadap Pertumbuhan Laba. Salamah (2019) dengan sampel 33 Perusahaan ada Perusahaan Sub Sektor Property dan Real Estate yang terdaftar di BEl Periode 2014-2017. Menunjukkan hasil bahwa DER memiliki pengaruh terhadap Pertumbuhan Laba. Sementara CR, NPM dan ROE tidak memiliki pengaruh terhadap Pertumbuhan Laba.

Prakarsa (2019) dengan sampel 15 Perusahaan Pada Perusahaan Sektor Pertambangan yang Terdaftar di Bursa Efek Indonesia Periode 2013-2015. Menunjukkan hasil bahwa QR, DER dan ITO memiliki pengaruh terhadap Pertumbuhan Laba. Sementara DR dan TATO tidak memiliki pengaruh terhadap Pertumbuhan Laba. Pertiwi (2019) dengan sampel 10 Perusahaan Perbankan yang Terdaftar di BEI Periode 2013-2017. Menunjukkan hasil bahwa Capital Adequacy Ratio dan Kepemilikan Manajerial secara parsial memiliki pengaruh terhadap Pertumbuhan Laba. Sementara Ukuran Perusahaan tidak memiliki pengaruh terhadap pertumbuhan laba.

Penelitian ini bertujuan menguji dan menganalisis pengaruh current ratio, debt to equity ratio, total asset turnover dan kepemilikan manajerial terhadap pertumbuhan laba.

\section{Kajian Literatur \& Perumusan Hipotesis}

\section{Teori Sinyal (Signaliing Theory)}

Brigham dan Housten (2014) isyarat atau signal adalah suatu tindakan yang diambil perusahaan untuk memberi petunjuk bagi investor tentang bagaimana manajemen memandang prospek perusahaan. Sinyal ini berupa informasi mengenai apa yang sudah dilakukan oleh manajemen untuk merealisasikan keinginan pemilik. Informasi yang dikeluarkan oleh perusahaan merupakan hal yang penting, karena pengaruhnya terhadap keputusan investasi pihak diluar perusahaan.

\section{Pertumbuhan Laba}

Harahap (2013) Pertumbuhan laba menunjukkan kemampuan perusahaan meningkatkan laba (deviden) bersih dibandingkan dengan tahun lalu. Laba merupakan informasi yang penting dalam sebuah laporan keuangan karena menggambarkan baik atau tidaknya perusahaan tersebut. Informasi pertumbuhan laba digunakan untuk mengevaluasi suatu kinerja perbankan 
setiap periode dan untuk memprediksi kondisi perusahaan dimasa mendatang. Harahap (2017) pengukuran pertumbuhan laba dapat diukur dengan rumus sebagai berikut :

$$
\text { Pertumbuhan Laba }=\frac{\text { Laba Bersih Tahun Ini }- \text { Laba Bersih Tahun Lalu }}{\text { Laba Bersih Tahun Lalu }}
$$

\section{Current Ratio}

Hanafi (2009) Current ratio dapat menjelaskan kemampuan perusahaan memenuhi hutang jangka pendeknya menggunakan aktiva lancarnya (aktiva yang akan merubah kas dalam waktu satu tahun atau satu siklus bisnis). Rasio ini merupakan ukuran yang paling umum digunakan untuk mengetahui kesanggupan memenuhi kewajiban jangka pendek, oleh karena itu rasio tersebut menunjukkan seberapa jauh tuntutan dari kreditor jangka pendek dipenuhi oleh aktiva yang diperkirakan menjadi uang tunai dalam periode yang sama dengan jatuh tempo hutang. Hanafi dan Halim (2014) pengukuran curren ratio dapat diukur dengan rumus sebagai berikut :

$$
\text { Current Ratio }=\frac{\text { Aktiva Lancar }}{\text { Utang Lancar }}
$$

\section{Debt to Equity Ratio}

Debt to Equity Ratio adalah perbandingan antara total hutang atau total debts dengan total sharehoder's equity. Rasio Kasmir (2012) rasio ini digunakan untuk mengetahui perbandingan antara total utang dengan modal sendiri dan untuk mengetahui seberapa besar aktiva perusahaan dibiayai dari utang. Marlina (2009) pengukuran debt to equity ratio dapat diukur dengan rumus sebagai berikut :

$$
\text { Debt to Equity Ratio }=\frac{\text { Total Hutang }}{\text { Total Modal }}
$$

\section{Total Asset Turnover}

Kieso (2007) dalam Accounting Principles, Total Asset Turnover mengukur seberapa efisien sebuah perusahaan menggunakan asetnya untuk memperoleh penjualan. Rasio ini untuk mengetahui kemampuan perusahaan dalam menghasilkan penjualan berdasarkan total aktiva yang dimiliki perusahaan. Semakin tinggi total asset turnover berarti semakin efektif penggunaan aktiva tersebut. Hanafi (2009) pengukuran total asset turnover dapat diukur dengan rumus sebagai berikut :

$$
\text { Total Asset Turnover }=\frac{\text { Penjualan }}{\text { Total Aktiva }}
$$

\section{Kepemilikan Manajerial}

Melinda (2008) Kepemilikan Manajerial adalah proporsi saham biasa yang dimiliki oleh para manajemen (Direksi dan Komisaris) yang diukur dengan persentase jumlah saham manajemen. Semakin tinggi proporsi kepemilikan manajerial maka akan semakin baik kinerja perusahaan sehingga manajer akan termotivasi untuk meningkatkan kinerjanya untuk perusahaan tersebut. Susanti (2013) pengukuran kepemilikan manajerial dapat diukur dengan rumus sebagai berikut :

$$
\text { Kepemilikan Manajerial }=\frac{\text { Jumlah saham yang dimiliki manajer }}{\text { Jumlah saham yang beredar }}
$$




\section{Kerangka Konseptual}

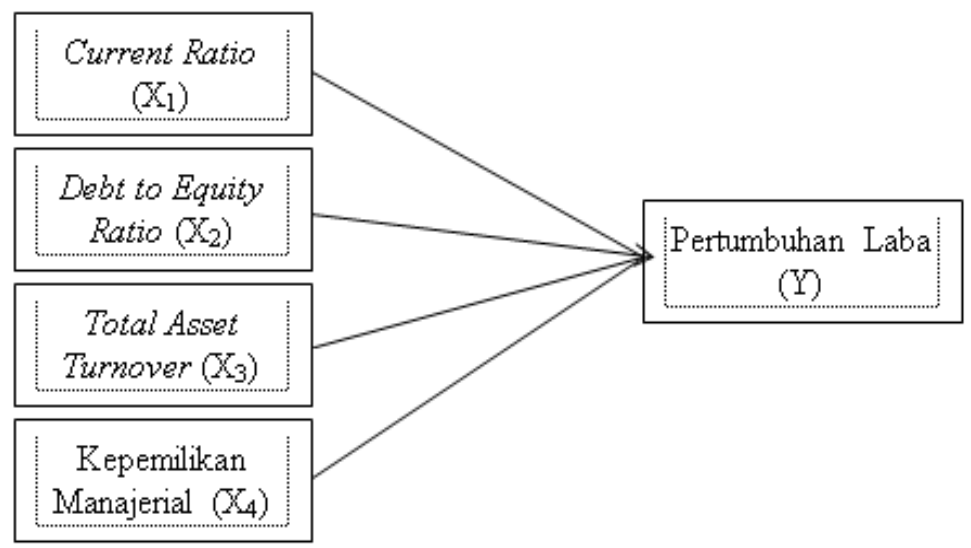

\section{HIPOTESIS}

Gambar 1. Kerangka Konseptual

\section{Pengaruh Current Ratio Terhadap Pertumbuhan Laba}

Hanafi (2009) current ratio digunakan untuk mengukur kemampuan perusahaan memenuhi hutang jangka pendeknya menggunakan aktiva lancarnya (aktiva yang akan merubah kas dalam waktu satu tahun atau satu siklus bisnis). Bati (2019) dengan 11 sampel Perusahaan Asuransi yang terdaftar di Bursa Efek Indonesia Periode 2014-2017 menunjukkan bahwa current ratio berpengaruh terhadap pertumbuhan laba. Jadi dapat diajukan hipotesis sebagai berikut

$\mathrm{H}_{1}$ : Current Ratio berpengaruh terhadap Pertumbuhan Laba

\section{Pengaruh Debt to Equiy Ratio Terhadap Pertumbuhan Laba}

Prihantoro (2009) semakin rendah debt to equity ratio akan semakin tinggi kemampuan perusahaan untuk membayar semua kewajibannya. Semakin besar penggunaan hutang maka dapat berdampak pada financial distress dan kebangkrutan. Prakarsa (2019) dengan sampel 15 Perusahaan Sektor Pertambangan yang terdaftar di Bursa Efek Indonesia menunjukkan bahwa debt to equity ratio berpengaruh terhadap pertumbuhan laba. Jadi dapat diajukan hipotesis sebagai berikut

$\mathrm{H}_{2}$ : Debt to Equity Ratio berpengaruh terhadap Pertumbuhan Laba

\section{Pengaruh Total Asset Turnover Terhadap Pertumbuhan Laba}

Pudjiastuty (2004) total asset turnover merupakan ukuran tentang sampai seberapa jauh aktiva ini telah dipergunakan di dalam kegiatan perusahaan atau menunjukkan berapa kali operating asset berputar dalam suatu periode tertentu. Semakin tinggi total asset turnover berarti semakin efektif penggunaan aktiva tersebut. Pangaribuan (2017) dengan sampel 22 Perusahaan Non Bank yang tergabung dalam Kelompok LQ45 yang terdaftar di Bursa Efek Indonesia menunjukkan bahwa total asset turnover berpengaruh terhadap pertumbuhan laba. Jadi dapat diajukan hipotesis sebagai berikut $\mathrm{H}_{3}$ : Total Asset Turnover berpengaruh terhadap Pertumbuhan Laba

\section{Pengaruh Kepemilikan Manajrial Terhadap Pertumbuhan Laba}

Susanti (2013) Semakin tinggi proporsi kepemilikan manajerial maka akan semakin baik kinerja perusahaan sehingga manajer akan termotivasi untuk meningkatkan kinerjanya untuk perusahaan tersebut Pertiwi (2019) dengan sampel 10 Perusahaan Perbankan yang terdaftar di Bursa Efek Indonesia menunjukkan bahwa Kepemilikan Manajerial berpengaruh terhadap pertumbuhan laba. Jadi dapat diajukan hipotesis sebagai berikut $\mathrm{H}_{4}$ : Kepemilikan Manjaerial berpengaruh terhadap Pertumbuhan Laba 


\section{METODE PENELITIAN}

Penelitian ini menggunakan metode kuantitatif karena data yang digunakan berupa angkaangka yang bersumber dari laporan keuangan. Menurut Sugiyono (2016) penelitian kuantitatif adalah penelitian dengan memperoleh data yang berbentuk angka atau data kualitatif yang diangkakan.

Populasi yang digunakan dalam penelitian ini adalah perusahaan sub sektor perbankan yang terdaftar di Bursa Efek Indonesia (BEI) tahun 2016-2018 sebanyak 45 perusahaan. Kriteria sampel ditentukan dengan metode purposive sampling (1) perusahaan sub sektor perbankan yang terdaftar secara konsisten dan menerbitkan laporan keuangan secara lengkap di Bursa Efek Indonesia periode 2016-2018, (2) perusahaan sub sektor perbankan yang mengalami laba / rugi selama periode pengamatan periode 2016-2018, (3) perusahaan sub sektor perbankan yang menerbitkan dalam rupiah selama periode pengamatan periode 2016-2018. Dari kriteria tersebut didapat sampel sebanyak 20 perusahaan.

Sumber data yang digunakan dalam penelitian ini adalah data sekunder berupa laporan keuangan perusahaan sub sektor perbankan yang terdaftar di Bursa Efek Indonesia (BEI) tahun 2016-2018. Pengujian hipotesis menggunakan analisis regresi linear berganda dan uji asumsi klasik. Sugiyono (2009) Model regresi dalam penelitian ini adalah :

a. Uji Asumsi Klasik

1. Uji Normalitas menggunakan metode uji one sample Kolmogrov-smirnov

2. Uji Multikolinearitas, dengan melihat nilai Tolerance dan Inflation Factor (VIF) pada model regresi

3. Uji Autokorelasi dengan melihan nilai yang ada pada Durbin-Watson

4. Uji Heteroskedastisitas dengan menggunakan metode korelasi Spearman'sh

b. Model Regresi

Uji $\mathrm{H}_{1}-\mathrm{H}_{4}$ diukur menggunakan model persamaan regresi linier berganda sebagai berikut:

Keterangan :

$$
Y=\alpha+\beta_{1} X_{1}+\beta_{2} X_{2}+\beta_{3} X_{3}+\beta_{4} X_{4}+e
$$

Y : Pertumbuhan Laba

a : Konstanta

$\mathrm{X}_{1}$ : Current Ratio

$\mathrm{X}_{2}$ : Debt to Equity Ratio

$\mathrm{X}_{3}$ : Total Asset Turnover

$\mathrm{X}_{4}$ :Kepemilikan Manajerial

e : Eror

c. Uji Hipotesis

1. Uji kelayan model (Uji F)

2. Uji hipotesis $t$

3. Uji koefisien determinasi

\section{HASIL DAN PEMBAHASAN}

Tabel 1. Kriteria Pemilihan Sampel

\begin{tabular}{clc}
\hline No & \multicolumn{1}{c}{ Keterangan } & Jumlah \\
\hline 1 & $\begin{array}{l}\text { Perusahaan Sub Sektor } \\
\text { Perbankan yang terdaftar di BEI } \\
\text { periode 2016-2018 }\end{array}$ & 45 \\
\hline 2 & $\begin{array}{l}\text { Perusahaan yang menyajikan } \\
\text { laporan keuangan tidak lengkap }\end{array}$ & $(5)$ \\
\hline 3 & $\begin{array}{l}\text { Perusahaan yang mengalami } \\
\text { kerugian selama periode } \\
\text { pengamatan }\end{array}$ & $(20)$ \\
\hline 4 & Perusahaan yang menjadi sampel & 20 \\
\hline
\end{tabular}




\begin{tabular}{clc}
\hline No & \multicolumn{1}{c}{ Keterangan } & Jumlah \\
\hline 5 & Jumlah persyaratan (3 tahun) & 60 \\
\hline 6 & Data Outlier & $(7)$ \\
\hline & Jumlah Persyaratan & 53 \\
\hline
\end{tabular}

Tabel 2. Uji Normalitas

\begin{tabular}{cccc}
\hline \multicolumn{1}{c}{ Variabel } & Sig & Syarat & Keterangan \\
\hline $\begin{array}{l}\text { Unstandarized } \\
\text { residual }\end{array}$ & 0,068 & $>0,05$ & Data Terdistribusi \\
Numbal
\end{tabular}

Sumber : Lampiran

Berdasarkan tabel 2 Uji normalitas data menggunakan statistik Kolomogorov-Smirnov Test dengan tarif signifikansi 0,05 sehingga data dinyatakan normal apabila nilai sig $>0,05$. Dari tabel IV. 3 tersebut nilai sig dinyatakan sebesar 0,068 sehingga dapat disimpulkan bahwa data tersebut terdistribusi normal.

Tabel 3. Uji Multikolinieritas

\begin{tabular}{lccccl}
\hline \multicolumn{1}{c}{ Variabel } & Tolerance & Syarat & VIF & Syarat & Keputusan \\
\hline $\begin{array}{l}\text { Current } \\
\text { Ratio }\end{array}$ & 0,572 & $>0,1$ & 1,748 & $<10$ & $\begin{array}{l}\text { Tidak Terjadi } \\
\text { multikolinieritas }\end{array}$ \\
\hline $\begin{array}{l}\text { Debt to } \\
\text { Equity Ratio }\end{array}$ & 0,630 & $>0,1$ & 1,588 & $<10$ & $\begin{array}{l}\text { Tidak Terjadi } \\
\text { multikolinieritas }\end{array}$ \\
\hline $\begin{array}{l}\text { Total Asset } \\
\text { Turnover }\end{array}$ & 0,948 & $>0,1$ & 1,055 & $<10$ & $\begin{array}{l}\text { Tidak Terjadi } \\
\text { multikolinieritas }\end{array}$ \\
\hline $\begin{array}{l}\text { Kepemilikan } \\
\text { Manajerial }\end{array}$ & 0,882 & $>0,1$ & 1,134 & $<10$ & $\begin{array}{l}\text { Tidak Terjadi } \\
\text { multikolinieritas }\end{array}$ \\
\hline
\end{tabular}

Sumber : Lampiran

Berdasarkan tabel 3 bahwa nilai Variance Inflation Factor (VIF) untuk variabel current ratio $\left(X_{1}\right)$ sebesar 1,748 , variabel debt to equity ratio $\left(X_{2}\right)$ sebesar 1,588 , variabel total asset turnover $\left(X_{3}\right)$ sebesar 1,055 dan variabel kepemilikan manajerial $\left(X_{4}\right)$ sebesar 1,134 demikian juga nilai Tolerence pada current ratio sebesar 0,572 , variabel debt to equity ratio sebesar 0,630 , variabel total asset turnover sebesar 0,948 dan variabel kepemilikan manajerial sebesar 0,882 . Dari masing-masing variabel bebas memiliki nilai tolerance lebih besar dari 0,1 dan VIF lebih kecil dari 10, sehingga dapat disimpulkan bahwa variabel bebas dalam penelitian ini tidak saling berkorelasi secara signifikan. Hasil penelitian menunjukkan bahwa data yang dianalisis memenuhi syarat multikolinieritas.

Tabel 4. Uji Autokorelasi

\begin{tabular}{cccccc}
\hline DW & DU & 4-DL & 4-DU & Kriteria & Keputusan \\
\hline & 1,7223 & 2,724 & 2,158 & DU $<$ DW $<4-$ & Tidak Terjadi \\
2,158 & & & & DU & Autokorelasi \\
\hline
\end{tabular}

Sumber : Lampiran

Berdasarkan tabel 4 Uji autokorelasi menggunakan uji durbin-watson dengan kriteria nilai $\mathrm{DU}<\mathrm{DW}<4$-DU dalam penelitian ini nilai kriteria $1,7223<2,158<2,158$ sesuai dengan kriteria diatas yang berarti koefisien regresi bebas dari gangguan autokorelasi.

Tabel 5. Uji Heteroskedastisitas

\begin{tabular}{lccc}
\hline \multicolumn{1}{c}{ Variabel } & Sig & Syarat & Kesimpulan \\
\hline $\begin{array}{l}\text { Current } \\
\text { Ratio }\end{array}$ & 0,169 & $>0,05$ & $\begin{array}{c}\text { Tidak Terjadi } \\
\text { Heteroskedastisitas }\end{array}$ \\
\hline
\end{tabular}




\begin{tabular}{lccc}
\hline Variabel & Sig & Syarat & Kesimpulan \\
\hline $\begin{array}{l}\text { Debt to } \\
\text { Equity Ratio }\end{array}$ & 0,724 & $>0,05$ & $\begin{array}{c}\text { Tidak Terjadi } \\
\text { Heteroskedastisitas }\end{array}$ \\
\hline $\begin{array}{l}\text { Total Asset } \\
\text { Turnover }\end{array}$ & 0,462 & $>0,05$ & $\begin{array}{c}\text { Tidak Terjadi } \\
\text { Heteroskedastisitas }\end{array}$ \\
$\begin{array}{l}\text { Kepemilikan } \\
\text { Manajerial }\end{array}$ & 0,847 & $>0,05$ & $\begin{array}{c}\text { Tidak Terjadi } \\
\text { Heteroskedastisitas }\end{array}$ \\
\hline Sumber : Lampiran & &
\end{tabular}

Berdasarkan tabel 5 heteroskedastisitas dalam penelitian ini menggunakan metode Spearman's rho. Pengujian menggunakan tingkat signifikansi 0,05. Berdasarkan uji heteroskedastisitas dinyatakan bahwa nilai signifikansi dari semua variabel bebas adalah lebih besar dari 0,05 , sehingga dapat disimpulkan bahwa bebas heteroskedastisitas dan data terdistribusi secara normal.

Tabel 6. Model Regresi

\begin{tabular}{lcc}
\hline \multicolumn{1}{c}{ Model } & B & Sig \\
\hline Pertumbuhan Laba & 0,145 & 0,856 \\
\hline Current Ratio & 0,274 & 0,543 \\
\hline Debt to Equity Ratio & $-0,035$ & 0,030 \\
\hline Total Asset Turnover & $-1,499$ & 0,365 \\
\hline $\begin{array}{l}\text { Kepemilikan } \\
\text { Manajerial }\end{array}$ & 2,805 & 0,000 \\
Sumber : Lampiran & &
\end{tabular}

Berdasarkan data 6 dapat disimpulkan bahwa persamaan regresi yang dibentuk adalah $Y=0,145+0,274 X_{1}-0,035 X_{2}-1,499 X_{3}+2,805 X_{4}$

Keterangan :

1. Konstanta sebesar 0,145 menunjukkan bahwa jika variabel independen yaitu current ratio, debt to equity ratio, total asset turnover dan kepemilikan manajerial di asumsikan bernilai nol (0) maka nilai pertumbuhan laba adalah 0,145.

2. Nilai koefisien Current Ratio sebesar 0,274 dengan arah hubungannya positif, menunjukkan apabila variabel current ratio meningkat sebesar $100 \%$ maka pertumbuhan laba meningkat sebesar $27,4 \%$ dengan asumsi variabel independen lainnya bernilai nol.

3. Nilai koefisien Debt to Equity Ratio sebesar -0,035 dengan arah hubungannya negatif menunjukkan apabila variabel debt to equity ratio meningkat sebesar $100 \%$ maka pertumbuhan laba menurun sebesar $-3,5 \%$ dengan asumsi variabel independen lainnya dianggap konstanta.

4. Nilai koefisien Total Asset Turnover sebesar -1,499 dengan arah hubungannya negatif menunjukkan apabila variabel total asset turnover meningkat sebesar $100 \%$ maka pertumbuhan laba menurun sebesar $-149,9 \%$ dengan asumsi variabel independen lainnya dianggap konstanta.

5. Nilai koefisien Kepemilikan Manajerial sebesar 2,805 dengan arah hubungannya positif, menunjukkan apabila variabel kepemilikan manajerial meningkat sebesar $100 \%$ maka pertumbuhan laba meningkat sebesar $280,5 \%$ dengan asumsi variabel independen lainnya bernilai nol.

Tabel 7. Uji F

\begin{tabular}{cccccc}
\hline Hipotesis & $F_{\text {hitung }}$ & $F_{\text {tabel }}$ & Sig & Syarat & Kesimpulan \\
\hline $\mathrm{Ha}$ & 8,728 & 2,79 & 0,000 & $<0,05$ & Simultan
\end{tabular}

Sumber : Lampiran

Berdasarkan tabel 7 dapat dilihat bahwa nilai $F_{\text {hitung }}$ lebih besar dari $F_{\text {tabel }}$ yaitu $8,728>2,79$ dan nilai signifikansi lebih kecil dari 0,05 yaitu 0,000 , berdasarkan tabel uji $F$ 
menyatakan bahwa berarti current ratio, debt to equity ratio, total asset turnover dan kepemilikan manajerial secara simultan berpengaruh terhadap pertumbuhan laba.

Tabel 8. Uji t

\begin{tabular}{lccccc}
\hline Hipotesis & thitung $_{\text {table }}$ & Sig & Syarat & Kesimpulan \\
\hline $\begin{array}{l}\text { Current } \\
\text { Ratio }\end{array}$ & 0,613 & 2,010 & 0,543 & $<0,05$ & Ditolak \\
\hline $\begin{array}{l}\text { Debt to } \\
\text { Equity Ratio }\end{array}$ & 2,237 & 2,010 & 0,030 & $<0,05$ & Diterima \\
\hline $\begin{array}{l}\text { Total Asset } \\
\text { Turnover }\end{array}$ & 0,914 & 2,010 & 0,365 & $<0,05$ & Ditolak \\
\hline $\begin{array}{l}\text { Kepemilikan } \\
\text { Manajerial }\end{array}$ & 4,626 & 2,010 & 0,000 & $<0,05$ & Diterima \\
\hline $\begin{array}{l}\text { Sumber : Lampiran } \\
\text { Sumberan }\end{array}$
\end{tabular}

Sumber : Lampiran

Berdasarkan tabel 8 tersebut menunjukkan bahwa nilai signifikasi Current Ratio sebesar 0.543 menyatakan bahwa current ratio ditolak dengan hipotesis current ratio tidak berpengaruh terhadap pertumbuhan laba yang berarti current ratio menurun maka pertumbuhan laba akan ikut turun. Nilai signifikasi Debt to Equity Ratio sebesar 0,030 menyatakan bahwa debt to equity ratio diterima dengan hipotesis debt to equity ratio berpengaruh terhadap pertumbuhan laba yang berarti debt to equity ratio meningkat maka pertumbuhan laba akan ikut serta naik. Nilai signifikasi Total Asset Turnover sebesar 0,365 menyatakan bahwa total asset turnover ditolak dengan hipotesis total asset turnover tidak berpengaruh terhadap pertumbuhan laba yang berarti total asset turnover menurun maka pertumbuhan laba akan ikut serta turun. Nilai signifikasi kepemilikan manajerial sebesar 0,000 menyatakan bahwa kepemilikan manajerial diterima dengan hipotesis kepemilikan manajerial berpengaruh terhadap pertumbuhan laba yang berarti kepemilikan manajerial meningkat maka pertumbuhan laba akan ikut serta naik.

Tabel 9. Uji Koefisien Determinasi

\begin{tabular}{cc}
\hline $\begin{array}{c}\text { Adjusted } \\
\mathrm{R}^{2}\end{array}$ & Kesimpulan \\
\hline \multicolumn{2}{c}{ Berpengaruh sebesar } \\
0,426 & $42,6 \%$ \\
\hline Sumber : Lampiran
\end{tabular}

Berdasarkan tabel 9 menunjukkan angka koefisien determinasi yang dapat dilihat melalui Adjusted $\mathrm{R}^{2}$ adalah sebesar 0,426 yang berarti 42,6\% variasi Pertumbuhan Laba mempengaruhi Current Ratio, Debt to Equity Ratio, Total Asset Turnover dan Kepemilikan Manajerial Sedangkan 57,4\% menjelaskan variabel lain masih banyak yang harus diteliti kembali.

Pengaruh current ratio terhadap pertumbuhan laba dalam penelitian ini menunjukkan bahwa nilai t hitung 0,613 dengan tingkat signifikan 0,543. Hal ini berarti current ratio tidak berpengaruh terhadap pertumbuhan laba. Maka semakin besarnya current ratio maka semakin rendah pertumbuhan laba, besarnya current ratio terjadi karena kemampuan perusahaan memenuhi hutang jangka pendeknya menggunakan aktiva lancarnya (aktiva yang akan merubah kas dalam waktu satu tahun). Penelitian ini sejalan dengan penelitian Yanti (2017), Utami (2019) dan Salamah (2019).

Pengaruh debt to equity ratio terhadap pertumbuhan laba dalam penelitian ini menunjukkan bahwa nilai t hitung -2,237 dengan tingkat signifikan 0,030. Hal ini berarti debt to equity ratio berpengaruh negatif dan signifikan terhadap pertumbuhan laba. Maka semakin rendah debt to equity ratio akan semakin tinggi kemampuan perusahaan untuk membayar hutangnya, ini berarti penggunaan hutang yang rendah perusahaan dapat mengalokasikan dividen tinggi sehingga sebagian besar keuntungan digunakan untuk kesejahteraan pemegang saham. Penelitian ini sejalan dengan penelitian Bati (2019) dan Prakarsa (2019) 
Pengaruh total asset turnover terhadap pertumbuhan laba dalam penelitian ini menunjukkan bahwa nilai t hitung $-0,914$ dengan tingkat signifikan 0,365 . Hal ini berarti total asset turnover tidak berpengaruh terhadap pertumbuhan laba. Maka semakin rendah total asset turnover penjualan bersih perusahaan lebih kecil dari pada operating asset perusahaan dalam meningkatkan pertumbuhan laba, ini berarti perusahaan masih kurang efektif dalam mengelola seluruh aktivanya. Penelitian ini sejalan dengan penelitian Riyadi (2017).

Pengaruh kebijakan manajerial terhadap pertumbuhan laba dalam penelitian ini menunjukkan bahwa nilai t hitung 4,626 dengan tingkat signifikan 0,000 . Hal ini berarti kebijakan manajerial berpengaruh terhadap pertumbuhan laba. Maka semakin besar saham yang dimiliki manajer, pihak manajemen akan semakin berhati hati dalam pengambilan keputusan dan mengurangi risko masalah keagenan yang dapat mempengaruhi pertumbuhan laba perusahaan. Penelitian ini sejalan dengan penelitian Pertiwi (2019).

\section{KESIMPULAN}

Penelitian ini bertujuan untuk mengetahui pengaruh current ratio, debt to equity ratio, total asset turnover dan kebijakan manajerial terhadap pertumbuhan laba. Populasi dalam penelitian ini adalah perusahaan sub sektor perbankan yang terdaftar di BEI periode 20162018 dengan metode purposive sampling diperoleh sampel sebanyak 20 perusahaan. Analisis yang digunakan adalah uji regresi linier berganda. Hasilnya adalah current ratio tidak berpengaruh terhadap pertumbuhan laba, debt to equity ratio berpengaruh negatif dan signifikan terhadap pertumbuhan laba, total asset turnover tidak berpengaruh terhadap pertumbuhan laba dan kebijakan manajerial berpengaruh terhadap pertumbuhan laba.

Berdasarkan kesimpulan diatas, maka saran bagi penelitian selanjutnya adalah memperluas objek serta sampel penelitian, tidak hanya perusahaan sub sektor perbankan saja tetapi bisa ditambah dengan perusahaan sektor industri dan kimia, perusahaan barang konsumsi, Selain itu nilai adjusted $\mathrm{R}^{2}$ juga hanya sebesar $42,6 \%$ yang berarti masih banyak faktor lain yang dapat mempengaruhi pertumbuhan laba namun belum diuji dalam penelitian ini. Penelitian selanjutnya sebaiknya menambahkan variabel lain seperti Good Corporate Governance, manajemen laba, CSR, ukuran perusahaan, nilai perusahaan serta dengan variabel yang dapat memperkuat pengaruh variabel independen terhadap variabel dependen seperti nilai perusahaan, harga saham dan non debt tax shield.

\section{DAFTAR PUSTAKA}

Brigham, E. \&. (2014). Dasar- Dasar Manajemen Keuangan. Jakarta: Salemba Empat. Hanafi, M., \& Halim (2009) Analisis Laporan Keuangan. Yogyakarta: UPP STIM YKPN. Hanafi, M., \& Halim, A. (2014). Analisis Laporan Keuangan. Yogyakarta: UPP STIM YKPN. Harahap, S. S. (2013). Analisis Kritis atas Laporan Keuangan. Edisi 11. Jakarta: Rajawali Pers.

Harahap, S. (2017). Teori Akuntansi. Jakarta: PT Raja Grafindo Persada.

Imanta, Dea dan Satwiko Rutji. (2011). Faktor-Faktor yang mempengaruhi Kebijakan Manajerial. Jurnal Bisnis dan Akuntansi, Vol. 13, No 1, april, hlm 67-80.

Irawati, Susan. (2006). Manajemen Keuangan. Bandung: Pusraka

Kasmir. (2012). Analisis Laporan Keuangan. Jakarta: PT Raja Grafindo Persada

Kasmir. (2017). Manajemen Perbankan, Edisi 11. Jakarta: Rajawali Pers,

Kieso, Jerry J. Weygandt, and Terry D. Warfield (2007). Akuntansi Intermediate. Edisi 12. Jakarta: Erlangga.

Marlina, Lisa, dan Carla Danica. (2009). Analisis Pengaruh Cash Position, Debt to Equity Ratio, Return On Asset Terhadap Divident Payout Ratio. Jurnal Manajemen Bisnis, Vol. 2, No. 1, Januari 2009:1-6.

Melinda, F. I. \& Sutejo, B. S (2008) Interdependensi Kepemilikan Manajerial dan Kepemilikan Institusional serta Pengaruhnya terhadap Kinerja Keuangan, Jurnal Ekonomi Bisnis, 7(2), 1-10. 
Prihantoro, (2009). Pengaruh Dividen Payout Ratio pada perusahaan public di Indonesia. Jurnal Ekonmi dan Bisnis. No 1, Jilid 8.

Pudjiastuty, E. (2004). Dasar-Dasar Manajemen Keuangan. Edisi 7. Yogyakarta: UPP STIM YKPN.

Sawir, A. (2003). Kebijakan Pendanaan dan Restrukturisasi Perusahaan. Edisi 3. Jakarta : Gramedia Pustaka Utama.

Sugiyono. (2016). Metode Penelitian Bisnis. Edisi 15 Bandung : Alfabeta.

Susanti, S., \& Riharjo, I. B. (2013). Pengaruh Good Corporate Governance Terhadap Corporate Social Responsibility Pada Perusahaan Cosmetic and Household. Jurnal IImu dan Riset Akuntansi. 1(1), 152-167.

Tarigan, I. (2009). Kepemilikan Manajerial; Kebijakan Hutang, Kinerja dan Nilai Perusahaan. Jurnal Akuntansi dan Keuangan, 9(1), 1-8. 